\title{
Pembentukan Keluarga Sakinah Pada Keluarga Jama'ah Tablig Di Kota Palangka Raya
}

\author{
Rachmad \\ IAIN Palangka Raya \\ Rachmadpky76@gmail.com
}

\begin{abstract}
In this study, used descriptive avalitative research with the subjeck using purposive sampling. That to be a respondent is a people's. A people of muslim religious teacher, and 3 people's from society that is community such a religious meeting. The objeck is a formation of harmonious family in the community such a religious in Palangkaraya Raya city. The data collection, it used some techniques such as interview, and documentation . for the data validity using triangulasi and analyzing the technique are as follows : data colection, data reduction, data display and conclusion. The main research finding were: 1) the method to making the harmonious family must be loving, to know and function in a family, know basic right and obligation in family. In a family must to ask and more than read a book about marriage, always to communication, to believe and understanding disvantages and advantages in family and always discussion. If a aplly can their be harmonious family. 2) All of agrrement their is no the problem to making the harmonious family. 3) The method to making the harmonious family is a ablution, reading Alquran or reading a Yasin, trust in.
\end{abstract}

Keywoard: Harmonious, community such a religious.

\section{A. Pendahuluan}

Perkawinan menurut hukum positif adalah ikatan lahir batin antara seorang pria dengan seorang wanita dengan tujuan membentuk keluarga atau rumah tangga yang bahagia dan kekal berdasarkan Ketuhanan Yang Maha Esa. ${ }^{1}$ Keluarga merupakan suatu perwujudan berkumpulnya laki-laki dan perempuan yang disatukan dalam suatu perkawinan atau pernikahan, yang menghasilkan keturunan yaitu anak. Alquran menjelaskan tujuan perkawinan atau membentuk sebuah keluarga yaitu untuk memenuhi kebutuhan fitrah manusia yang cenderung terhadap pasangannya, agar manusia memperoleh ketenangan dan kebahagiaan. Selain itu, untuk beribadah kepada Allah, menjaga kehormatan dan untuk memperoleh keturunan. Dalam hal menjaga kehormatan, untuk memperoleh keturunan Allah Swt, telah menerangkan

${ }^{1}$ Lihat Undang-undang No. 1 tahun 1974 bab II pasal 2 dan 3 Tentang Perkawinan 
di dalam firman-Nya tentang ciptaan-Nya yang terdiri dua jenis manusia yang berbeda kelamin, yaitu laki-laki dan perempuan. Mereka diberi peluang untuk saling mengenal, saling mencari jodoh, dan untuk membina keluarga sebagai pasangan suami istri yang membangun rumah tangga.

Terjemahan : Hai manusia, sesungguhnya kami menciptakan kamu dari seorang laki-laki dan seorang perempuan dan menjadikan kamu berbangsa- bangsa dan bersuku-suku supaya kamu saling kenal mengenal. Sesungguhnya orang yang paling mulia di antara kamu di sisi Allah ialah orang yang paling bertakwa di antara kamu. Sesungguhnya Allah Maha Mengetahui lagi Maha Mengenal. $^{2}$

Ayat di atas dapat dipahami bahwa diciptakan laki-laki dan perempuan itu berpasangan mulai saling mengenal dari latar yang berbeda. Kemudian Allah Swt meningkatkan kualitas perkenalan itu dengan saling berjodohan, maka menjadi pasangan suami istri yang sah melalui Aqad Nikah dan Ijab Qabul, untuk membangun dan membina sebuah rumah tangga. Membangun dan membina rumah tangga dalam Islam semua manusia pasti memiliki tujuan pernikahan. Banyak sekali tujuan - tujuan dari pernikahan ini yang merupakan suatu landasan utama seseorang menjalin sebuah hubungan atau membangun suatu keluarga. Tujuan tersebut sesuai dengan ketentuan yang terdapat di Q.S an-Nisa [4:1].

Keluarga yang di dasarkan dengan ajaran agama dapat dijadikan sebuah strategi atau pencapaian menuju keluarga yang sakinah yang merupakan suatu cita-cita dari setiap pasangan suami dan istri. Menurut kaidah bahasa Indonesia, sakinah mempunyai arti kedamaian, ketentraman, ketenangan, kebahagiaan. Keluarga sakinah mengandung makna keluarga yang diliputi rasa damai juga tentram. Keluarga sakinah adalah kondisi yang sangat ideal dalam kehidupan keluarga. Sakinah dapat diartikan dengan damai atau tenang dan tentram adalah semakna dengan sa'adah yang bermakna bahagia, dengan arti

${ }^{2} \mathrm{Al}$ Hujuraat [49]: 13. 
keluarga sakinah adalah keluarga yang bahagia, keluarga yang penuh rasa kasih sayang dan memperoleh rahmat Allah. ${ }^{3}$

Sakinah dalam keluarga adalah sebagai metode/ jalan menuju tujuan perkawinan yang sesuai dengan syariat yaitu mawaddah wa rahmah. Sakinah itu penting karena tanpa ketenangan dan keamanan hati, banyak masalah yang tidak dapat diselesaikan. Pentingnya sakinah dalam sebuah keluarga membuat penulis ingin meneliti kehidupan ataupun rumah tangga pada jama'ah tablig. Apakah sakinah yang dimiliki sesuai dengan konsep ajaran islam maupun undang- undang yang berlaku.

Penulis melakukan observasi awal dari data browsing dilanjutkan dengan silaturrahmi sekaligus wawancara awal dengan informen. Observasi awal ini bertujuan ingin mengetahui kondisi umum mengenai keluarga sakinah jama'ah tablig di kota Palangka Raya. Penulis peroleh informasi awal sebagai berikut: Keluarga Jama'ah Tablig terbuka kepada siapapun yang ingin memperdalam ilmu agama islam. Lebih banyak berada di luar rumah daripada di dalam rumah dalam hal berdakwah atau menyampaikan ajaran islam; Pemikiran mereka lebih kuat kepada ilmu tauhid; Dari hasil observasi tersebut penulis tertarik untuk meneliti pembentukan keluarga sakinah pada keluarga jama'ah tablig di kota Palangka Raya dengan berbagai alasan. Pertama, penelitian ini sangat penting karena sampai saat ini belum ada penelitian yang menjelaskan kehidupan dan landasan jama'ah tablig membentuk sebuah keluarga yang sakinah di kota Palangka Raya. Kedua, penelitian ini sangat bagus untuk dilanjutkan karena dari hasil observasi awal penulis banyak menemukan suatu kendala atau masalah kehidupan keluarga sehingga penulis tertarik untuk mengetahui bagaimana keluarga jama'ah tablig di kota Palangka Raya mengatasi problem tersebut.

Berdasarkan pemikiran pada latar belakang di atas, penulis ingin menggali dan meneliti pembentukan keluarga sakinah pada keluarga

${ }^{3}$ Lihat Lubis Salam, Menuju Keluarga Sakinah,Surabaya: Terbit Terang,2007, hal. 7 
jama'ah tablig yang sesuai dengan hukum Islam. Berdasarkan latar belakang di atas, penulis sangat tertarik mengangkat permasalahan tersebut untuk mengkajinya lebih mendalam yang dituangkan dalam sebuah karya ilmiah yang berjudul: "PEMBENTUKAN KELUARGA SAKINAH PADA KELUARGA JAMA'AH TABLIG DI KOTA PALANGKA RAYA”.

\section{B. Kajian Pustaka}

Berdasarkan hasil pencarian terhadap penelitian-penelitian sebelumnya, baik berasal dari perpustakaan, website, dan sebagainya penulis menemukan kajian atau penelitian tentang keluarga sakinah dan jama'ah tablig diakui sudah pernah ada yang meneliti. Beberapa penelitian tersebut adalah: Aktivitas Pembinaan Amaliyah Agama Islam Jama'ah Tablig Kelurahan Baamang Tengah Kecamatan Baamang Kabupaten Kotawaringin Timur oleh Rusli. Penelitian ini terfokus pada aktivitas pembinaan amaliyah bil lisan dan bil hal jama'ah tablig kelurahan Baamang Tengah kecamatan Baamang kabupaten Kotawaringin Timur. Hasil penelitian ini adalah: Aktivitas pembinaan amaliyah bil lisan jama'ah tablig meliputi: Ta'lim wa Ta'allum yaitu termasuk didalamnya pengajaran bimbingan tata cara wudhu, shalat serta niat dan bacaan-bacaannya. Hal yang menarik dari Ta'alim wa Ta'allum adalah para jama'ah mengemukakan pengalaman atau pengetahuan dalam hal ibadah yang di dapat sebelum menjadi pengikut jama'ah tablig kemudian dibahas apakah yang didapat selama ini sudah benar atau tidak kemudian dan diberi arahan supaya menjadi baik. Bayan, berisi tentang penanaman nilai-nilai keimanan, nasehat- nasehat kepada anggota yang lalai melaksanakan ibadah terutama shalat fardhu. Hal menarik adalah setelah selesai menyampaikan materi dalam bayan para anggota diberi tawaran untuk ke luar dalam rangka Tablig. Tawaran itu dapat dipilih sesuai dengan kemampuan yaitu ada yang 3 hari,20 hari, 40 hari, 3 bulan dan 6 bulan. Ta'lim yaitu berisi tentang motivasi ibadah, supaya anggota bersemangat melaksanakan ibadah. Aktivitas pembinaan amaliyah bil hal jama'ah tablig, meliputi: pengamalan sebagian sunah rasul, 
seperti: tata cara, berpakaian, makan dan minum serta tidur. Dari sebagian sunnah rasul yang diterapkan itu hal yang menarik adalah cara berpakaian, mengenakan pakaian jubah dan surban di kepala dan apabila menggunakan sarung atau celana panjang tidak boleh lebih dari mata kaki, kemudian cara makan yang hanya menggunakan tiga jari, dan ketika minum tidak boleh bernapas, cara memegang gelas; jari manis berada di bawah gelas sebagai penahan gelas, jari tengah, telunjuk dan jempol mengapit gelas. ${ }^{4}$

Strategi Dakwah Jama'ah Tabligh Di Kota Palangka Raya. (Studi di Masjid Raudhatul Jannah dan Masjid Shalahuddin) oleh Muhidin. Penelitian ini terfokus pada strategi apa yang jama'ah tablig gunakan dalam berdakwah serta bagaimana strategi dakwah Jama'ah Tabligh di Masjid Raudhatul Jannah dan Masjid Shalahudin di Kota Palangka Raya. Hasil penelitian ini adalah: Strategi Khuruj (keluar) dan Jaulah (keliling) yang digunakan Jama'ah Tabligh mendapat perhatian dari masyarakat kota Palangka Raya, Khususnya di Masjid Raudhatul Jannah dan Masjid Shalahudin. Strategi Khuruj (keluar) dan Jaulah (keliling) Jama'ah Tabligh gunakan dalam berdakwah nampaknya belum sepenuhnya terlaksana. Strategi dakwah yang dilakukan oleh Jama'ah Tabligh di Masjid Raudhatul Jannah dan Masjid Shalahudin Palangka Raya pada umumnya menggunakan cara dan metode yang khusus yaitu Khuruj (Keluar) untuk memperbanyak anggota baru di kota Palangka Raya, Strategi lain yang digunakan oleh Jama'ah Tabligh selama melakukan gerakan dakwah menggunakan strategi jaulah. ${ }^{5}$

Itulah beberapa penelitian yang dilakukan sebelumnya dan sampai sekarang tampaknya penulis tidak menemukan adanya penelitian serupa selain dari yang dijelaskan di atas. Persamaan penelitian terdahulu dengan

\footnotetext{
${ }^{4}$ Rusli, Aktivitas Pembinaan Amaliyah Agama Islam Jama'ah Tablig Kelurahan Baamang Tengah Kecamatan Baamang Kabupaten Kotawaringin Timur, (skripsi). Palangka Raya: STAIN Palangka Raya, 2001, h. Iv.

${ }^{5}$ Muhidin, Strategi Dakwah Jama'ah Tabligh Di Kota Palangka Raya (Studi di Masjid Raudhatul Jannah dan Masjid Shalahuddin), (skripsi). Palangka Raya: STAIN Palangka Raya,2005, h. 74-75.
} 
penelitian yang penulis teliti adalah sama-sama membahas tentang jama'ah tablig. Sedangkan perbedaannya adalah penelitian yang dilakukan Rusli adalah fokus kepada aktivitas pembinaan agama islam Jama'ah Tablig. Dan penelitian Muhidin, fokus yang ditelitinya tentang strategi dakwah Jama'ah Tablig di kota Palangka Raya.. Sedangkan penelitian penulis memfokuskan pada pembentukan keluarga sakinah dan cara mengatasi kendala pada keluarga jama’ah tablig di kota Palangka Raya.

Adapun tujuan dari penelitian ini adalah sebagai berikut: Untuk mengetahui cara keluarga jama'ah tablig di kota Palangka Raya membentuk keluarga sakinah. Untuk mengetahui apa saja kendala yang dihadapi dalam pembentukan. Untuk mengetahui cara mengatasi kendalakendala dalam pembentukan keluarga sakinah pada keluarga jama'ah tablig di kota Palangka Raya. Penelitian ini merupakan penelitian lapangan dengan menggunakan pendekatan kualitatif deskriptif. Lebih spesifik penelitian ini disebut dengan penelitian sosiologis dalam hukum Islam. Data primer adalah data empiris yang diperoleh langsung dari sumber data, jadi bukan hasil olahan orang lain. ${ }^{6}$ Sumber data yang dimaksud dalam penelitian hukum ini sebagaimana disebutkan oleh Abdulkadir Muhammad yaitu:

Lokasi penelitian, yaitu lingkungan tempat dilakukannya penelitian. Oleh karena itu, data primer sering disebut dengan data lapangan. Peristiwa hukum yang terjadi di lokasi penelitian. Responden yang memberikan informasi kepada peneliti. Bogdan dan Taylor sebagaimana dikutip oleh Lexy J. Moleong dalam bukunya yang berjudul Metodologi Penelitian Kualitatif mendefinisikan metodologi kualitatif sebagai prosedur penelitian yang menghasilkan data deskriptif berupa kata-kata tertulis atau lisan dari orang-orang dan perilaku yang dapat diamati. Definisi serupa juga disebutkan oleh Kirk dan Miller dalam buku tersebut yang mendefinisikan bahwa penelitian kualitatif adalah tradisi tertentu dalam ilmu pengetahuan sosial yang secara fundamental bergantung

${ }^{6}$ Abdulkadir Muhammad, Hukum dan Penelitian Hukum, Cet. 1, Bandung: Citra Aditya Bakti, 2004, h. 170. 
terhadap pengamatan pada manusia dalam kawasannya sendiri dan berhubungan dengan orang-orang tersebut dalam bahasanya dan dalam peristilahannya. $^{7}$

\section{Metodologi Penelitian}

Penelitian ini terfokus pada strategi apa yang jama'ah tablig gunakan dalam berdakwah serta bagaimana strategi dakwah Jama'ah Tabligh di Masjid Raudhatul Jannah dan Masjid Shalahudin di Kota Palangka Raya. Hasil penelitian ini adalah: Strategi Khuruj (keluar) dan Jaulah (keliling) yang digunakan Jama'ah Tabligh mendapat perhatian dari masyarakat kota Palangka Raya, Khususnya di Masjid Raudhatul Jannah dan Masjid Shalahudin. Strategi Khuruj (keluar) dan Jaulah (keliling) Jama'ah Tabligh gunakan dalam berdakwah nampaknya belum sepenuhnya terlaksana. Strategi dakwah yang dilakukan oleh Jama'ah Tabligh di Masjid Raudhatul Jannah dan Masjid Shalahudin Palangka Raya pada umumnya menggunakan cara dan metode yang khusus yaitu Khuruj (Keluar) untuk memperbanyak anggota baru di kota Palangka Raya, Strategi lain yang digunakan oleh Jama'ah Tabligh selama melakukan gerakan dakwah menggunakan strategi jaulah. ${ }^{8}$

\section{Pembahasan}

Pada penelitian ini peneliti mengambil subjek sebanyak 4 orang, yakni terdiri dari 1 orang ulama dan 3 orang masyarakat yang termasuk anggota jamaah tablig kota Palangka Raya untuk dijadikan sebagai key informan dalam pengambilan data di lapangan dengan uraian sebagai berikut:

${ }^{7}$ Lexi J. Moeleong, Metodologi Penelitian Kualitatif, Cet. 18, Bandung: PT. Remaja Rosdakarya, 2004,h.3.

${ }^{8}$ Muhidin, Strategi Dakwah Jama'ah Tabligh Di Kota Palangka Raya (Studi di Masjid Raudhatul Jannah dan Masjid Shalahuddin), (skripsi). Palangka Raya: STAIN Palangka Raya,2005, h. 74-75. 


\section{Persepsi Jama'ah Tablig Di Kota Palangka Raya Tentang}

Pembentukan Keluarga Sakinah. Pada tanggal 29 September 2013, penulis pergi mengunjungi rumah $\mathrm{KM}$ dan penulis bertemu dengan Beliau disana, beliau adalah Ulama yang sangat dikenal oleh masyarakat kota Palangka Raya, selain sebagai anggota jama'ah tablig kota Palangka Raya, beliau adalah pensiunan kanwil departemen agama kota Palangka Raya. Berikut adalah hasil wawancara dengan KM tentang pembentukan keluarga sakinah:

"membentuk keluarga sakinah itu dengan mengetahui serta paham kedudukan dan fungsi yang tertuang dalam BP4. Suami dan istri harus mematuhi nasihat dari keluarga seperti ayah, ibu, penghulu, atau petugas karena itu yang penting. Suami dan istri harus suka bertanya dan rajin membaca buku tentang perkawinan, atau buku nikah.

Pertama perkenalan awal, hanya dari muka lalu menjalin cinta dan kasih sayang, tidak perlu teori pendidikan karena tidak membantu memahami agama, secara sempurna".

Setelah itu, penulis menanyakan kepada KM tentang kendala dan cara mengatsi kendala dalam pembentukan keluarga sakinah: Kendala yang berarti selama khuruj tidak ada. Meskipun ada, dapat diselesaikan oleh keluarga. Karena setiap musibah yang datang pada keluarga yang ditinggalkan cara mengatasinya hanya dengan berwudhu, sholat 2 rakaat, wasilah baca yasin, dan tawakal. Iman, apapun masalah bukan aku yang menyembuhkan namun Allah. Sebelum khuruj telah musyawarah dengan keluarga dalam hal nafkah, pendidikan, dll. Selama khuruj ada yang meninggal ikhlas karena Allah. Kalau mati ya mati, dengan datangnya saya gak bakalan kan hidup lagi. Kalau sakit ya sakit, ada aja dokter Pokoknya kalau ada masalah tidak bakalan diberi izin oleh keluarga, karena sampai saat ini tidak ada, diberi izin tarus". 9

Pada tanggal 29 September 2013, penulis menemui subjek MN seusai wawancara dari rumah keluarga KM, sebab menurut saran KM untuk melanjutkan wawancara kepada MN. Berikut hasil wawancara dengan MN tentang pembentukan keluarga sakinah:

${ }^{9}$ Wawancara dengan KM, Tanggal 29 September 2013 di rumah KM, Pukul 08.30 Wib. 
"cara membentuk keluarga yang sakinah, caranya mengalir aja dari kacamata dakwah karena ada musyawarah. Pentingnya khuruj sama dengan pentingnya saling menjaga.

Setelah itu, penulis menanyakan kepada MN tentang kendala dan cara mengatasi kendala dalam pembentukan keluarga sakinah:

Kendala selama khuruj tidak ada, karena setiap malam kami selalu musyawarah. Walaupun salah satu dari kami sudah meninggal musyawarah akan tetap dijalankan setiap malam. Sebelum khuruj semua telah dipersiapkan, seperti nafkah yang sengaja disiapkan, nafkah harta telah diperhitungkan 75 ribu $\times 120$ hari $=9$ juta tambah dengan dana tak terduga untuk setiap kali berangkat khuruj selama 4 bulan". Kita kembalikan kepada Allah, semua keluarga sepakat, kita belajar dengan sunnah." 10

Pada tanggal 29 September 2013, penulis pergi mengunjungi AR ke kediaman beliau namun lama untuk di bukakan pintu rumah karena lagi istirahat siang, akhirnya tidak lama kemudian penulis berhasil bertemu dengan beliau. Berikut adalah hasil wawancara dengan AR:

"cara membentuk keluarga sakinah yaitu saling percaya, saling mengerti kelebihan dan kekurangan masing-masing, hidupkan amalan (sholat, didik anak, baca Al-qur' an, dll. Persiapan untuk khuruj di haji dan atau kerja luar persiapkan seperti orang berangkat.

Setelah itu, penulis menanyakan kepada $\mathrm{KM}$ tentang kendala dan cara mengatsi kendala dalam pembentukan keluarga sakinah:

Tidak ada masalah atau kedala, karena kalau siap Allah yang menjaga.tapi kalau uang atau nafkah keluarga yang ditinggal tidak cukup berarti belum saatnya. Sabar aja dulu."11

Pada tanggal 30 September 2013, penulis mendatangi rumah kediaman MR dan bertemu di kediaman MR. Berikut hasil wawancara dengan MR mengenai pembentukan keluarga sakinah:

"cara membentuk keluarga sakinah adalah dengan saling komunikasi, saling memahami dan patuh akan kedudukannya masing-masing. Menurut saya keluarga sakinah itu ialah keluarga yang didalam nya damai, tentram,dll.

Setelah itu, penulis menanyakan kepada KM tentang kendala dan cara mengatsi kendala dalam pembentukan keluarga sakinah:

${ }^{10}$ Wawancara dengan MN, Tanggal 29 September 2013 di rumah MN, Pukul: 09.00 Wib

${ }^{11}$ Wawancara dengan AR, Tanggal 29 September 2013 di Kediaman AR, Pukul: 10.30 Wib. 
Kendala yang dihadapi tidak ada, karena sebelum berangkat khuruj keluarga telah berpesan dan yang pergi khuruj telah meninggalkan nafkah harta, dll."12

\section{Cara Keluarga Jama'ah Tablig Di Kota Palangka Raya}

Membentuk Keluarga Sakinah. Cara membentuk keluarga yang sakinah, khususnya di kota Palangka Raya adalah hal yang perlu diperhatikan bagi setiap keluarga. Cara tersebut sudah umum dan sering di dengar bagi pasangan yang baru melasungkan pernikahan karena telah terdapat dalam BP 4 serta nasihat dari penghulu atau petugas KUA. Hal ini apabila dilihat dalam segi hukum islam sebagaimana pendapat ulama dari kelompok jama'ah tablig di kota Palangka Raya pada umumnya semua keluarga yang ingin membentuk keluarga sakinah adalah dengan menjalin cinta dan kasih sayang. Sebagaimana dalam Alquran dijelaskan melalui surah Ar- Ruum ayat 21 berikut:

Terjemahan :dan di antara tanda-tanda kekuasaan-Nya ialah Dia menciptakan untukmu isteri-isteri dari jenismu sendiri, supaya kamu cenderung dan merasa tenteram kepadanya, dan dijadikan-Nya diantaramu rasa kasih dan sayang. Sesungguhnya pada yang demikian itu benar-benar terdapat tanda-tanda bagi kaum yang berfikir.

Ayat Alquran tadi menjelaskan bahwa keluarga yang sakinah adalah keluarga yang memiliki rasa kasih dan sayang. Karena dalam keluarga tidak bisa berdiri sendiri harus saling melengkapi. Berdasarkan hasil wawancara terhadap 4 subjek penelitian yang penulis jadikan sebagai subjek penelitian, ternyata anggota jama'ah tablig di kota Palangka Raya sangat beragam berpendapat dalam memandang cara pembentukan keluarga sakinah. Empat orang subjek penelitian yakni KM, MN, AR dan MR. Menurut KM, suami istri itu harus paham kedudukan dan fungsi masing-masing keluarga agar tidak ada kesalahpahaman dalam hal mengurus dan atau mencari semua yang berhubungan dengan keluarga.

${ }^{12}$ Wawancara dengan AR, Tanggal 29 September 2013 di Kediaman AR, Pukul: 13.00 
Suami istri paham hak dan kewajiban masing-masing. sebagaimana dalam Alquran dijelaskan melalui surah berikut:

Terjemahan : Hai orang-orang yang beriman, tidak halal bagi kamu mempusakai wanita dengan jalan paksa dan janganlah kamu menyusahkan mereka karena hendak mengambil kembali sebagian dari apa yang telah kamu berikan kepadanya, terkecuali bila mereka melakukan pekerjaan keji yang nyata. Dan bergaullah dengan mereka secara patut. Kemudian bila kamu tidak menyukai mereka, (maka bersabarlah) karena mungkin kamu tidak menyukai sesuatu, padahal Allah menjadikan padanya kebaikan yang banyak Dalam ayat lain juga dijelaskan bahwa pelihara keluarga kalian dari api neraka dari apa yang menjurumuskan ke api neraka. Dengan kata lain keluarga yang di antara suami dan istri tahu apa hak dan kewajiban masing- masing agar keluarganya dapat terhindar dari api neraka.

\section{Kendala Yang Dihadapi Dalam Pembentukan Keluarga Sakinah}

\section{Pada Keluarga Jama'ah Tablig Di Kota Palangka Raya. Dalam} penelitian ini, yang menjadi subyek utama adalah kepala yang berperan penuh dalam pembentukan keluarga sakinah. Sama halnya dengan keluarga jama'ah tablig pembentukan keluarga sakinah peran pentingnya berada di kepala keluarga atau suami meskipun kepala keluarga sering melakukan khuruj (bepergian untuk berdakwah fi sabilillah). Kendala yang dihadapi dalam pembentukan keluarga sakinah, menurut KM, MN, AR, dan MR sepakat mengatakan bahwa semua kendala dalam pembentukan keluarga sakinah yang berarti tidak ada. Menurut KM, kendala dalam pembentukan keluarga sakinah itu ada namun dapat di selesaikan oleh keluarga. Untuk kendala yang berarti tidak ada. Menurut KM, kendala yang ada selama KM pergi khuruj selama setahun pada tahun 2011-2012 seperti nafkah, musibah, ataupun meninggalnya adik kandung dari KM. Menurut MN, kendala dalam pembentukan kelurga sakinah tidak ada karena kalau seandainya ada kendala, keluarga yang ditinggal dapat menyelesaikan. Seperti nafkah keluarga seperti pembiayaan kuliah dan pembelian beras. Menurut AR dan MR sepakat untuk mengatakan bahwa kendala yang berarti itu tidak ada. 
Berdasarkan hal di atas ditemukan suatu kesimpulan bahwa bagi keluarga Jama'ah Tablig tidak ada kendala dalam pembentukan keluarga sakinah. Menurut penulis, pandangan tersebut berhubungan dengan pola pikir Jama'ah Tablig itu sendiri yang menganggap bahwa semua hal sudah di tentukan Allah SWT. Tapi menurut pengamatan penulis di lapangan kendala dalam pembentukan.

\section{Cara Mengatasi Kendala-Kendala Dalam Pembentukan} Keluarga Sakinah Pada Keluarga Jama'ah Tablig Di Kota Palangka Raya. Cara mengatasi suatu kendala merupakan suatu jalan penyelesaian dalam suatu keluarga. Dalam penelitian ini, cara mengatasi kendala tersebut banyak jalannya seperti halnya keluarga jama'ah tablig saat meninggalkan keluarga untuk khuruj yang menyelesaikan kendala atau mengatasi kendala yang ada dengan berbagai cara. Menurut KM, cara mengatasi kendala saat KM sedang khuruj atau berdakwah itu banyak caranya. Seperti kendala KM saat khuruj keluarga yang ditinggalkan terjadi musibah maka cara mengatasi kendala tersebut dengan wudhu dan sholat 2 rakaat, wasilah baca yasin untuk keluarga yang terkena musibah, dan tawakal kepada Allah. Dan saat adik kandung beliau meninggal dunia melalui kabar telepon, KM melakukan cara tersebut. Karena menurut $\mathrm{KM}$, selama khuruj apapun musibah yang datang belum tentu saya pulang itu menyelesaikannya. Senada dengan KM, menurut MN, AR, dan MR semua kendala itu pasti ada penyelesaiannya meskipun itu tanpa kepala keluarga. Karena semua sudah dipersiapkan untuk mengatasi kendala tersebut. Dengan cara, sebelum khuruj telah di persiapkan kesiapan keluarga yang ditinggal dengan memberikan perhatian atau penjelasan mengapa harus pergi khuruj, memberikan uang (nafkah) secukupnya atau yang telah di hitung secara keseluruhan, telah kompromi atau di jelaskan untuk semua keluarga seperti dalam hal membantu mengatasi kendala-kendala selama kepala keluarga melaksanakan khuruj atau berdakwah. Berdasarkan analisis penulis, cara mengatasi kendala dalam pembentukan keluarga sakinah menurut keluarga jama'ah tablig 
adalah dengan melakukan berberapa hal berwudhu, sholat sunah 2 rakaat, wasilah baca yasin, dan tawakal kepada Allah. Berwudhu yang di maksud adalah berwudhu ketika mau sholat yang dengan tujuan dapat menenangkan pikiran dan batin seseorang yang sedang mengalami atau mendapatkan musibah atau kendala.

Sholat sunah 2 rakaat yang dimaksud adalah sholat sunah yang sesuai pada waktunya, seperti sholat dhuha yang dilaksanakan antara pagi dan pagi menjelang siang. Wasilah baca yasin yang dimaksud adalah membaca ayat Allah yang tujuannya untuk di hadiahkan kepada seseorang dengan di dasari dengan niat yang ingin di tujukan, seperti baca yasin dengan niat karena Allah dan dihadiakan kepada seseorang. Dan tawakal yang dimaksud adalah suatu perilaku yang terahir di lakukan setelah melakukan usaha atau perbuatan, seperti pada keluarga jama'ah tablig yang meninggalkan keluarga saat melakukan khuruj dengan beberapa bekal atau nafkah yang di tinggal dan setelahnya tawakal kepada Allah Swt agar Allah Swt menjaga keluarga yang di tinggalkan. Menurut analisis penulis cara penyelesaian tersebut sangat sesuai dengan ajaran islam karena cara penyelesaian yang di pakai tidak menyalahi dalam agama islam itu sendiri atau sesuai dengan hukum islam.

Berdasarkan analisis penulis, dari pembentukan, kendala serta mengatasi kendala dalam pembentukan keluarga sakinah pada keluarga jama'ah tablig di kota Palangka Raya telah mengarah pada teori tentang kriteria keluarga sakinah. Dalam hal ini, dari 4 subjek yang di teliti dan berdasarkan analisis keluarga jama'ah tablig di kota Palangka Raya bahwa keluarga tersebut termasuk dalam kriteria keluarga sakinah I. Karena dalam kriteria keluarga sakinah I semua komponen telah terpenuhi oleh 4 subjek yang merupakan keluarga jama'ah tablig. 


\section{E. Kesimpulan}

Dari uraian dan pembahasan yang telah dikemukakan maka hasil penelitian ini dapat disimpulkan sebagai berikut: Dari empat subjek yang penulis teliti ialah KM, MN, AR dan MR. Satu diantaranya seorang ulama dan tiga diantaranya masyarakat biasa yang termasuk dalam anggota jama'ah tablig, mereka sepakat berpendapat bahwa dalam cara pembentukan keluarga yang sakinah harus memiliki dan menjalin rasa kasih serta sayang, Paham kedudukan dan fungsi masing- masing di dalam keluarga, Paham hak dan kewajiban masing-masing dalam keluarga, Dalam keluarga harus suka bertanya, rajin membaca buku tentang perkawinan, selalu komunikasi, percaya dan mengerti kekurangan serta kelebihan masing-masing keluarga, dan musyawarah setiap saat. Apabila di aplikasikan maka akan terciptanya sebuah keluarga yang sakinah. Adapun pendapat dari subjek sangat beragam tentang kendala yang dihadapi dalam pembentukan keluarga sakinah. Namun semua sepakat bahwa kendala yang berarti dalam pembentukan keluarga sakinah itu tidak ada. Menurut MN, AR, serta MR sepakat bahwa cara mengatasi kendala dalam pembentukan keluarga sakinah adalah dengan musyawarah. Dan menurut KM cara menyelesaikan kendala dalam pembentukan keluarga sakinah yaitu dengan cara berwudhu, sholat sunah 2 rakaat, wasilah baca yasin, sertan tawakal kepada Allah.

\section{Daftar Pustaka}

Undang-undang No. 1 tahun 1974 bab II pasal 2 dan 3 Tentang Perkawin

Lubis Salam, Menuju Keluarga Sakinah,Surabaya: Terbit Terang,2007, hal. 7

Muhidin, Strategi Dakwah Jama'ah Tabligh Di Kota Palangka Raya (Studi di Masjid Raudhatul Jannah dan Masjid Shalahuddin), (skripsi). Palangka Raya: STAIN Palangka Raya,2005, h. 74-75.

Abdulkadir Muhammad, Hukum dan Penelitian Hukum, Cet. 1, Bandung: Citra Aditya Bakti, 2004, h. 170. 
Lexi J. Moeleong, Metodologi Penelitian Kualitatif, Cet. 18, Bandung: PT. Remaja Rosdakarya, 2004,h.3.

Wawancara dengan KM, Tanggal 29 September 2013 di rumah KM, Pukul 08.30 Wib.

Wawancara dengan MN, Tanggal 29 September 2013 di rumah MN, Pukul: 09.00 Wib

Wawancara dengan AR, Tanggal 29 September 2013 di Kediaman AR, Pukul: 10.30 Wib. 